\title{
Lidocaine for Status Epilepticus in Pediatrics
}

\author{
Frederick A. Zeiler, Kaitlin J. Zeiler, Jeanne Teitelbaum, Lawrence M. Gillman, \\ Michael West, Colin J. Kazina
}

\begin{abstract}
Background: Our goal was to perform a systematic review of the literature on the use of intravenous lidocaine in pediatrics for status epilepticus (SE) and refractory status epilepticus (RSE) to determine its impact on seizure control. Methods: All articles from MEDLINE, BIOSIS, EMBASE, Global Health, HealthStar, Scopus, Cochrane Library, the International Clinical Trials Registry Platform (inception to November 2014), and gray literature were searched. The strength of evidence was adjudicated using both the Oxford and Grading of Recommendations Assessment, Development, and Evaluation methodologies by two independent reviewers. Results: Overall, 20 original studies were identified, with 19 manuscripts and one meeting abstract. Two hundred and thirty-five pediatric patients were treated for 252 episodes of SE/RSE. Patients had varying numbers of antiepileptic drugs (two to eight) on board before lidocaine therapy. During 20 of the 252 (7.9\%) episodes of SE/RSE, phenytoin was on board. The dose regimen of lidocaine varied, with some using bolus dosing alone; others used a combination of bolus and infusion therapy. Overall, $60.0 \%$ of seizures responded to lidocaine, with complete cessation and greater than $50 \%$ reduction seen in $57.6 \%$ and $12.3 \%$, respectively. Patient outcomes were sparingly reported. Conclusions: There currently exists Oxford level 2b, Grading of Recommendations Assessment Developement, and Evaluation C evidence to support the consideration of lidocaine for SE and RSE in the pediatric population. Further prospective studies of lidocaine administration in this setting are warranted.
\end{abstract}

RÉSUMÉ: Traitement de l'état de mal épileptique par la lidocaïne en pédiatrie. Contexte : Nous avons effectué une revue systématique de la littérature à propos de l'utilisation de la lidocaïne par voie intraveineuse chez des enfants en état de mal épileptique (ÉMÉ) ou d'ÉMÉ résistant au traitement (ÉMÉR) afin de déterminer son impact sur le contrôle de l'ÉMÉ. Méthode : Nous avons recherché tous les articles sur ce sujet indexés dans MEDLINE, BIOSIS, EMBASE, Global Health, HealthStar, Scopus, Cochrane Library, the International Clinical Trials Registry Platform (du début jusqu' à novembre 2014) ainsi que la documentation parallèle. Deux réviseurs indépendants ont utilisé l'Oxford and Grading of Recommendations Assessment, Development and Evaluation pour évaluer la qualité des études. Résultats : En tout, 20 études originales ont été identifiées, dont 19 manuscrits et un résumé. Deux cent trente-cinq patients d'âge pédiatrique ont ainsi été traités au cours de 252 épisodes d'ÉMÉ/ÉMÉR. Les patients recevaient plusieurs médicaments antiépileptiques (de 2 à 8 ) avant le traitement par la lidocaïne. Au cours de 20 des 252 épisodes d'ÉMÉ/ÉMÉR (7,9\%), le patient recevait de la phénytoïne. La dose de lidocaïne était variable : certains ont reçu seulement un bolus alors que d'autres ont reçu la lidocaïne en bolus et en perfusion. En tout, $60 \%$ des crises ont répondu à la lidocaïne avec arrêt complet de la crise chez $57,6 \%$ des patients et plus de $50 \%$ de réduction chez $12,3 \%$ des patients. Peu d'information était rapportée sur l'issue chez les patients. Conclusions : Il y a actuellement des données de niveau $2 \mathrm{~b}$, selon le Grading of Recommendations Assessment, Development and Evaluation C, à l'appui de l'utilisation de la lidocaïne pour traiter l'ÉMÉ et l'ÉMÉR chez les patients d'âge pédiatrique. Il serait donc justifié de procéder à des études prospectives sur l'utilisation de la lidocaïne dans ce contexte.

Keywords: clinical pharmacology, epilepsy, epilepsy - pediatric, neurocritical care, neurology - neonatal, neurology - pediatric, pediatric neurology, pediatrics, seizures, status epilepticus

doi: $10.1017 / \operatorname{cjn} .2015 .278$

Can J Neurol Sci. 2015; 42: 414-426

Status epilepticus (SE) and refractory status epilepticus (RSE) can be difficult to manage in the pediatric and neonatal populations. Concerns over drug reactions and interactions in the developing child pose potential limitations to antiepileptic drug (AED) selection in the setting of SE and RSE. ${ }^{1-3}$

Current management options for SE and RSE in the pediatric/ neonatal patient population include, but are not limited to: benzodiazepines, barbiturates, phenytoin, levetiracetam, carbamazepine, and lidocaine ${ }^{4}$-all of which have displayed varying efficacy at seizure control in SE and RSE. ${ }^{4-7}$

Lidocaine, a class Ib antiarrhythmic agent, has known sodium channel-based AED properties in both the adult and pediatric populations stemming back to the 1950 s. $^{8-11}$ Its potential summative benefit in the presence of other sodium channelmediated AEDs seem to be mediated by its amine chain motif and external sodium channel binding site. ${ }^{12-14}$ Using lidocaine to treat

From the Section of Neurosurgery, Department of Surgery, University of Manitoba, Winnipeg, Canada (FAZ, MW, CJK); Misericordia Health Center, Winnipeg, MB, Canada (KJZ); Section of Neurocritical Care, Montreal Neurological Institute, McGill, Montreal, Canada (JT); Section of Neurology, Montreal Neurological Institute, McGill, Montreal, Canada (JT); Section of Critical Care Medicine, Department of Medicine, University of Manitoba, Winnipeg, Canada (LMG); Section of General Surgery, Department of Surgery, University of Manitoba, Winnipeg, Canada (LMG). Received April 9, 2015. Final Revisions Submitted June 11, 2015. Correspondence to: Frederick A. Zeiler, Section of Neurosurgery, Department of Surgery, University of Manitoba, GB-1 820 Sherbrook Street, Winnipeg, MB, Canada R3A1R9. Email: umzeiler@cc.umanitoba.ca 
seizures is common in the pediatric literature. Of interest within a recent survey, the third commonly prescribed AED for neonatal seizures was lidocaine. ${ }^{4}$

Given the use of lidocaine as an AED in the pediatric and neonatal populations as reported in the literature to date, ${ }^{15-35}$ we decided to perform a systematic review to determine the effectiveness of lidocaine in controlling pediatric/neonatal SE and RSE.

\section{Methods}

A systematic review using the methodology outlined in the Cochrane Handbook for Systematic Reviewers ${ }^{36}$ was conducted. The data were reported following the Preferred Reporting Items for Systematic Reviews and Meta-Analyses. ${ }^{37}$ The review questions and search strategy were decided upon by the primary author (FAZ) and supervisor (MW).

\section{Search Question, Population, Inclusion, and Exclusion Criteria}

The question posed for systematic review was: What is the effectiveness of lidocaine for control of SE in human children? All studies, prospective and retrospective of any size based on human subjects, were included. The reason for an all-inclusive search was based on the small number of studies of any type identified by the primary author during a preliminary search of MEDLINE.

The primary outcome measure was electrographic seizure control. Secondary outcome measures were patient outcome (if reported) and adverse effects of lidocaine treatment. Inclusion criteria were: all studies including human subjects whether prospective or retrospective, all study sizes, pediatric patients (age younger than 18 years), any language, and the use of lidocaine for seizure control in SE. Exclusion criteria were adult and animal studies. Any non-English studies were translated.

\section{Search Strategy}

MEDLINE, BIOSIS, EMBASE, Global Health, SCOPUS, and Cochrane Library from inception to October 2014 were searched using individualized search strategies for each database. The search strategy for MEDLINE can be seen in supplementary Appendix A, with a similar search strategy used for the other databases. In addition, the World Health Organization's International Clinical Trials Registry Platform was searched looking for studies planned or underway.

As well, meeting proceedings for the past 5 years looking for ongoing and unpublished work based on lidocaine use for seizures were examined. The meeting proceedings of the following professional societies were searched: Canadian Neurological Sciences Federation, American Association of Neurological Surgeons, Congress of Neurological Surgeons, European Neurosurgical Society, World Federation of Neurological Surgeons, American Neurology Association, American Academy of Neurology, American Epilepsy Society, European Federation of Neurological Science, World Congress of Neurology, Society of Critical Care Medicine, Neurocritical Care Society, and the World Federation of Societies of Intensive and Critical Care Medicine, American Society for Anesthesiologists, World Federation of Societies of Anesthesiologist, Australian Society of Anesthesiologists, International Anesthesia Research Society, Society of Neurosurgical
Anesthesiology and Critical Care, Society for Neuroscience in Anesthesiology and Critical Care, and the Japanese Society of Neuroanesthesia and Critical Care.

Finally, reference lists of any review articles or systematic reviews on seizure management were reviewed for relevant studies on lidocaine usage for seizure control.

\section{Study Selection}

Using two reviewers (FAZ and KJZ), a two-step review of all articles returned by our search strategies was performed. First, the reviewers independently screened all titles and abstracts of the returned articles to decide if they met the inclusion criteria. Second, full text of the chosen articles was then assessed to confirm if the articles met the inclusion criteria and that the primary outcome of seizure control was reported in the study. Any discrepancies between the two reviewers were resolved by a third independent reviewer (MW).

\section{Data Collection}

Data were extracted from the selected articles and stored in an electronic database. Data fields included: patient demographics, type of study (prospective or retrospective), number of patients, dose and route of lidocaine administration used, timing to administration of drug, duration of drug administration, time to effect of drug, how many other AEDs were used before lidocaine, degree of seizure control, adverse effects, and patient outcome.

\section{Quality of Evidence Assessment}

Assessment of the level of evidence for each included study was conducted by two independent reviewers (FAZ and MW) using the Oxford criteria ${ }^{38}$ and the Grading of Recommendation Assessment Development and Education (GRADE) criteria ${ }^{39-44}$ for level of evidence.

The Oxford criteria consist of a five-level grading system for literature. Level 1 is split into subcategories $1 \mathrm{a}, 1 \mathrm{~b}$, and $1 \mathrm{c}$, which represent a systematic review of randomized control trials with homogeneity, individual randomized control trials with narrow confidence interval, and all or none studies, respectively. Oxford level 2 is split into $2 \mathrm{a}, 2 \mathrm{~b}$, and $2 \mathrm{c}$, representing systematic review of cohort studies with homogeneity of data, individual cohort study or low-quality randomized control trials, and outcomes research, respectively. Oxford level 3 is split into $3 a$ and $3 b$, representing systematic review of case-control studies with homogeneity of data and individual case-control study respectively. Oxford level 4 represents case-series and poor cohort studies. Finally, Oxford level 5 represents expert opinion.

The GRADE level of evidence is split into 4 levels: A, B, C, and D. GRADE level A represents high evidence with multiple high-quality studies having consistent results. GRADE level B represents moderate evidence with one high-quality study or multiple low-quality studies. GRADE level C evidence represents low evidence with one or more studies with severe limitations. Finally, GRADE level D represents very low evidence based on either expert opinion or few studies with severe limitations.

Any discrepancies between the grading of the two reviewers were resolved via discussion and a third reviewer when required (CJK). 


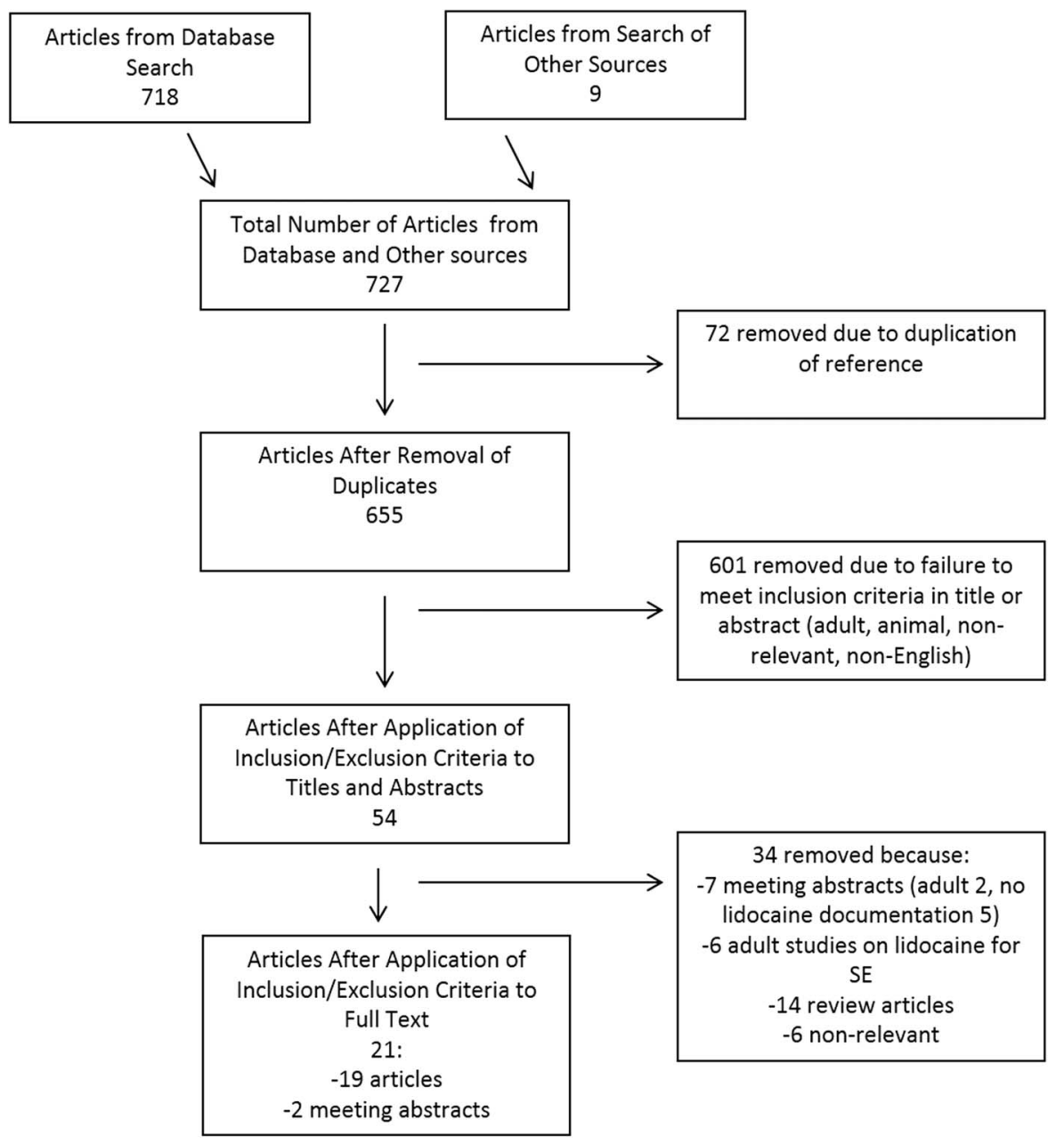

Figure 1: Flow diagram of search results.

\section{Statistical Analysis}

A meta-analysis was not performed in this study because of the heterogeneity of data within the articles and the small number of low-quality studies.

\section{RESULTS}

The results of the search strategy across all databases and other sources are summarized in Figure 1. Overall, a total of 727 articles were identified, with 718 from the database search and nine from the search of published meeting proceedings. Seventy-two duplicate references were removed, leaving 655 for analysis. By applying the inclusion/exclusion criteria to the title and abstract of the articles, we identified 54 articles that fit these criteria. Of the 54 identified, 45 were from the database search and nine were from published meeting proceedings. Applying the inclusion/exclusion criteria to the full-text documents, only 21 articles were eligible for inclusion in the systematic review, with 19 from the database and two from meeting proceeding sources. The 33 articles that were excluded were done so because they either did not report details around the administration of lidocaine for seizure control, were based on adult patients only, were nonrelevant studies, or because they were review articles. Upon review of the reference sections of relevant review articles, no additional articles were added.
Of the 21 articles included in the review, 20 were original studies, ${ }^{15-26,28-35}$ with one companion abstract publication identified. $^{27}$ The companion abstract was included for completeness $^{27}$ and was not included for the rest of the review to avoid duplication of patient data. There were 15 original retrospective studies ${ }^{15,16,18,20,21,23-26,28,30,32-35}$ and five prospective studies. ${ }^{17,19,22,29,31}$ Within the retrospective studies, 12 were retrospective case series $15,16,18,20,21,24,26,28,30,32,34,35$ and the remaining three were retrospective case reports. ${ }^{23,25,33}$ All studies were based in single centers. The five prospective studies included three prospective single-arm studies ${ }^{22,29,31}$ and two randomized control trials. ${ }^{17,19}$ The two randomized control trials compared lidocaine to benzodiazepine (midazolam or clonazepam) in the setting of RSE.

Across all studies, 235 patients were studied using lidocaine for control of their SE/RSE (mean: 11.8 patients/study; range: 1-46 patients/study), with a total of 252 separate episodes of SE/ RSE treated with lidocaine documented. Sixteen patients were studied as controls, using benzodiazepine-based therapies in the setting of RSE. ${ }^{17,19}$ The age of patients studied ranged from 25 weeks' gestational age to 16 years. Study demographics and patient characteristics for the pediatric studies can be seen in Table 1, whereas treatment characteristics and seizure outcome are reported in Table 2 . 


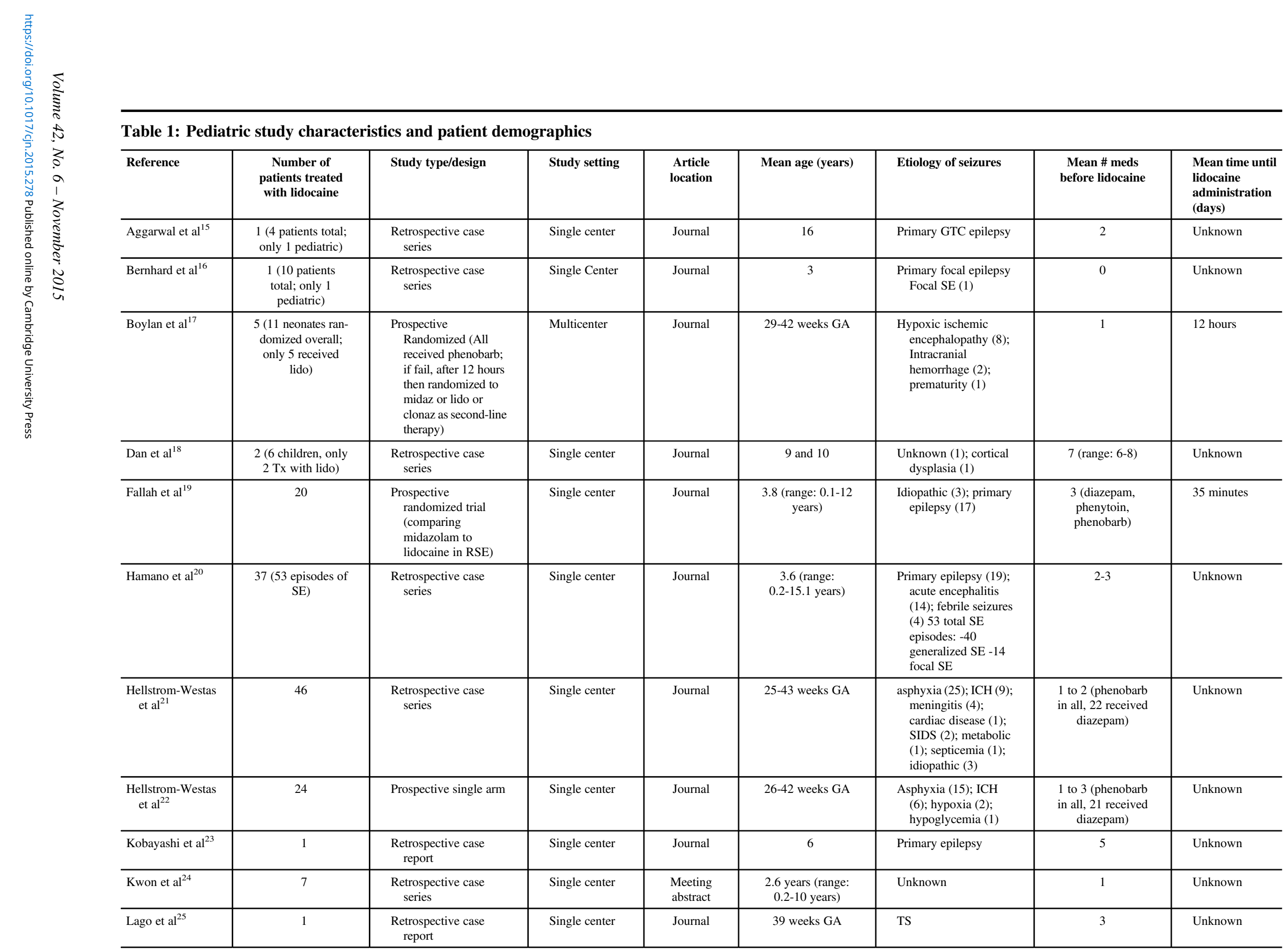




\begin{tabular}{|c|c|c|c|c|c|c|c|c|}
\hline Reference & $\begin{array}{c}\text { Number of } \\
\text { patients treated } \\
\text { with lidocaine }\end{array}$ & Study type/design & Study setting & $\begin{array}{l}\text { Article } \\
\text { location }\end{array}$ & Mean age (years) & Etiology of seizures & $\begin{array}{c}\text { Mean \# meds } \\
\text { before lidocaine }\end{array}$ & $\begin{array}{l}\text { Mean time until } \\
\text { lidocaine } \\
\text { administration } \\
\text { (days) }\end{array}$ \\
\hline Lin et $\mathrm{al}^{26 *}$ & $\begin{array}{c}\text { (9 total; only } 4 \\
\text { Tx with lido) }\end{array}$ & $\begin{array}{l}\text { Retrospective case } \\
\text { series }\end{array}$ & Single center & Journal & $\begin{array}{l}10 \text { years (range: } \\
9.1-14.5 \text { years) }\end{array}$ & AERRPS & 4 & Unknown \\
\hline Lin et $\mathrm{al}^{27} *$ & 3 & $\begin{array}{l}\text { Retrospective case } \\
\text { series }\end{array}$ & Single center & $\begin{array}{r}\text { Meeting } \\
\text { abstract }\end{array}$ & Range: 6-14 years & AERRPS & Unknown & $\begin{array}{l}9.3 \text { days (range: } \\
9-10 \text { days) }\end{array}$ \\
\hline Lundqvist et $\mathrm{al}^{28}$ & 30 & $\begin{array}{l}\text { Retrospective case } \\
\text { series }\end{array}$ & Single center & Journal & Unknown & Unknown & $\begin{array}{l}\text { 1-2 (benzodiaze- } \\
\text { pine infusions in } \\
\text { all) }\end{array}$ & Unknown \\
\hline Malingre et $\mathrm{al}^{29}$ & 20 & Prospective single arm & Single center & Journal & $\begin{array}{l}\text { Unknown } \\
\text { "neonates" }\end{array}$ & Unknown & $\begin{array}{c}2 \text { (phenobarb in } \\
\text { all; either midaz or } \\
\text { clonaz as second } \\
\text { agent) }\end{array}$ & Unknown \\
\hline 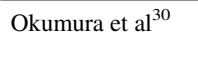 & $\begin{array}{l}1 \text { (2 cases; only } 1 \\
\text { Tx with lido) }\end{array}$ & $\begin{array}{l}\text { Retrospective case } \\
\text { series }\end{array}$ & Single center & Journal & 7 and 8 & $\begin{array}{l}\text { Acute encephalopathy } \\
\text { NYD }\end{array}$ & 3 & Unknown \\
\hline Rey et $\mathrm{al}^{31}$ & 13 & Prospective single arm & Single center & Journal & 29-42 weeks GA & $\begin{array}{l}\text { Asphyxia (10); } \\
\text { hypernatremia (1); } \\
\text { Listeria (1); } \\
\text { unknown (1) }\end{array}$ & $\begin{array}{c}2 \text { (all had pheno- } \\
\text { barb and } \\
\text { diazepam) }\end{array}$ & $0.2-4.3$ days \\
\hline Shany et $\mathrm{al}^{32}$ & $\begin{array}{c}22(30 \text { total; } 22 \mathrm{Tx} \\
\text { with lido, } 8 \text { with } \\
\text { midaz) }\end{array}$ & $\begin{array}{l}\text { Retrospective case } \\
\text { series }\end{array}$ & Single center & Journal & $1.5-9$ years & Asphyxia (30) & $\begin{array}{c}2 \text { (phenobarb and } \\
\text { benzo) }\end{array}$ & Unknown \\
\hline Wakamoto et $\mathrm{al}^{33}$ & 1 & $\begin{array}{l}\text { Retrospective case } \\
\text { report }\end{array}$ & Single center & Journal & 7.5 & Encephalitis Focal SE & 2 & Unknown \\
\hline Wallin et $\mathrm{al}^{34}$ & 3 & $\begin{array}{l}\text { Retrospective case } \\
\text { series }\end{array}$ & Single center & Journal & $\begin{array}{l}\text { Unknown } \\
\text { "neonates" }\end{array}$ & $\begin{array}{l}\text { asphyxia (2); } \\
\text { idiopathic (1) }\end{array}$ & $\begin{array}{l}\text { (Phenobarb and } \\
\text { diazepam in all) }\end{array}$ & $\begin{array}{l}3.6 \text { days (range: } \\
2-6)\end{array}$ \\
\hline Yamamoto et al $^{35}$ & $\begin{array}{l}16 \text { (65 total stu- } \\
\text { died; } 49 \text { midaz } \\
\text { only, } 10 \text { lido only, } \\
6 \text { both })\end{array}$ & $\begin{array}{l}\text { Retrospective case } \\
\text { series }\end{array}$ & Multicenter & Journal & 25-41 weeks GA & $\begin{array}{l}\text { Undefined number of } \\
\text { varying pathologies }\end{array}$ & $\begin{array}{l}\text { 6.3\% Hypotension, } \\
\text { hypersecretion, } \\
\text { abdominal } \\
\text { distension }\end{array}$ & \\
\hline
\end{tabular}

AERRPS, acute encephalitis with refractory repetitive partial seizures; benzo, benzodiazepine; clonaz, clonazepam; GA, gestational age; GTC, generalized tonic clonic; lido, lidocaine; midaz midazolam; NYD, not yet diagnosed; phenobarb, phenobarbital; TS, tuberous sclerosis; Tx, treatment.

* Lin et $\mathrm{al}^{26}$ and Lin et $\mathrm{al}^{27}$ contain duplicate data, with only the data from Lin et $\mathrm{al}^{26}$ included in the final summary of data. Lin et al ${ }^{27}$ is the published meeting abstract of Lin et al. ${ }^{26}$ 
A variety of underlying pathology leading to SE/RSE was reported within the 234 cases treated with lidocaine. The most commonly reported pathology was hypoxia/anoxia, primary epilepsy, encephalitis, and intracerebral hemorrhage. A large number of studies failed to specify the underlying cause of SE/RSE.

\section{Pre-Lidocaine Treatment Characteristics}

Duration of treatment before lidocaine administration was documented in five studies, ranging from 35 minutes to 10 days. Patients were on various numbers of AEDs before lidocaine, with the mean number of AEDs ranging from two to eight with most patient treatments typically consisting of a combination of oral AED and intravenous anesthetic agents. Of note, in 20 of the 234 (8.5\%) SE/RSE episodes described, phenytoin was on board during lidocaine administration. All AEDs reported as being used in management were typically on board during the lidocaine treatment. Similarly, the duration of lidocaine treatment was described in 10 of the 20 studies, with treatment duration ranging from one time bolus dosing, up to 36 days of continuous intravenous infusion. One patient was discharged with lidocaine transdermal patches, eventually being transitioned to mexilitine. $^{23}$

\section{Lidocaine Treatment Characteristics}

\section{The Retrospective Studies}

The literature on lidocaine use for control of SE/RSE in the pediatric population yielded 15 retrospective studies. ${ }^{15,16,18,20,21,23-26,28,30,32-35}$ Within these 15 studies, one used bolus dosing of lidocaine in isolation, ${ }^{15}$ with a dose of $100 \mathrm{mg}$ intravenously once.

Four studies used continuous infusions of lidocaine only, ${ }^{23,26,28,34}$ with dosing ranging from 1 to $8 \mathrm{mg} / \mathrm{kg} / \mathrm{hour}$. Of note, one of these studies ${ }^{23}$ transitioned from continuos infusion to lidocaine transdermal patch for maintenance therapy in a single patient. Duration of the lidocaine infusion was documented in only one study from this group, with duration ranging from 0.5 to 2.5 days. $^{28}$

Six studies used bolus dosing of lidocaine, followed by continuous infusions. ${ }^{16,20,21,24,25,32}$ The initial bolus ranged from $0.91 \mathrm{mg} / \mathrm{kg}$ to $4 \mathrm{mg} / \mathrm{kg}$ intravenously, typically given over 20 minutes (when documented). The infusion rates ranged up to 2 to $6 \mathrm{mg} / \mathrm{kg} /$ hour. The duration of the lidocaine infusions in this group of studies varied from 1 to 36 days, with three manuscripts failing to document duration of therapy. ${ }^{20,24,32}$

Finally, four studies failed to document the details of lidocaine dosing and administration. ${ }^{18,30,33,35}$ Lidocaine treatment characteristics can be seen in Table 2 .

\section{The Prospective Studies}

The literature on lidocaine use for control of SE/RSE in the pediatric population yielded five prospective studies. ${ }^{17,19,22,29,31}$ Within these, three were prospective single-arm studies. The first study was a prospective study of 24 patients with unspecified underlying etiology, treated with a 1.6 to $2.2 \mathrm{mg} / \mathrm{kg}$ bolus, followed by a continuous infusion at 4.7 to $6.3 \mathrm{mg} / \mathrm{kg} /$ hour, for a duration of 0.1 to 9.3 days. $^{22}$ The second study was a prospective study of 20 patients with unspecified underlying etiology, treated with $2 \mathrm{mg} / \mathrm{kg}$ intravenous bolus of lidocaine over 10 minutes, followed by continuous infusion for 36 hours. ${ }^{29}$ The infusion protocol was as follows: $6 \mathrm{mg} / \mathrm{kg} / \mathrm{hour}$ for 12 hours, then $4 \mathrm{mg} / \mathrm{kg} / \mathrm{hour}$ for 12 hours, and finally $2 \mathrm{mg} / \mathrm{kg} /$ hour for 12 hours. The final prospective single-arm study followed 13 patients with hypoxia as the predominant underlying etiology. ${ }^{31}$ These patients were administered continuous lidocaine infusions via the following protocol: $4 \mathrm{mg} / \mathrm{kg} /$ hour for $1 \mathrm{day}$, then $2 \mathrm{mg} / \mathrm{kg} /$ hour for 1 day, and finally $1 \mathrm{mg} / \mathrm{kg} /$ hour for 1 day for a total treatment duration of 3 days.

The two remaining prospective studies identified in this review were randomized control trials comparing lidocaine to benzodiazepine-based therapy. ${ }^{17,19}$

The first study was a randomized control trial of 11 patients with hypoxia as the predominant etiology of their SE. These patients had all received phenobarbitone as the first-line AED, and if failure of seizure control was noted at 12 hours they were randomized to one of three groups. One group $(n=5)$ received lidocaine bolus of $4 \mathrm{mg} / \mathrm{kg}$ over 20 minutes, followed by a continuous infusion at $2 \mathrm{mg} / \mathrm{kg} / \mathrm{hour}$ for an unspecified duration. If failure of lidocaine occurred at this point, the infusion dose was escalated to $4 \mathrm{mg} / \mathrm{kg} / \mathrm{hour}$ for 12 hours. If the seizures still failed to respond at this point the patient was removed from the trial. Another group $(n=3)$ received a midazolam bolus of $60 \mathrm{mcg} / \mathrm{kg}$ followed by an infusion of $150 \mathrm{mcg} / \mathrm{kg} /$ hour for 12 hours. If failure of midazolam occurred at this point, the infusion dose was escalated to $300 \mathrm{mcg} / \mathrm{kg} /$ hour for 12 hours. If the seizures still failed to respond at this point, the patient was removed from the trial. The final group $(n=3)$ received clonazepam at an unspecified dose and duration.

The second randomized trial followed 20 patients with primary epilepsy as predominant etiology of their SE. ${ }^{19}$ These patients all received diazepam $(0.2-0.3 \mathrm{mg} / \mathrm{kg}$ intravenous load twice), phenytoin $(15-20 \mathrm{mg} / \mathrm{kg}$ intravenous load), and phenobarbitone (10 mg/kg intravenous load over 10 minutes). If failure of these three AEDs occurred, patients were enrolled and randomized to receive either midazolam or lidocaine therapy. The midazolam group $(\mathrm{n}=10)$ received $0.15 \mathrm{mg} / \mathrm{kg}$ bolus followed by a continuous infusion of 1 to $6 \mathrm{mcg} / \mathrm{kg} /$ hour, titrated to effect, for a treatment duration of 24 hours. The lidocaine group $(n=10)$ received a $1 \mathrm{mg} / \mathrm{kg}$ bolus; if no response, then a second dose was given after 15 minutes followed by a continuous infusion at $5 \mathrm{mg} / \mathrm{kg} /$ hour for 12 hours. The infusion was then titrated off by $0.5 \mathrm{mg} / \mathrm{kg} /$ hour on an hourly basis. If a patient from either group failed, then therapy was stopped and pentobarbital was started.

\section{Seizure Response}

Overall, 174 of the $252(69.0 \%)$ SE/RSE episodes studied displayed seizure response to lidocaine administration. Complete seizure control upon lidocaine administration occurred in 143 of the $252(57.6 \%)$ SE/RSE episodes documented. A greater than $50 \%$ reduction in seizure frequency occurred in 31 of the 252 $(12.3 \%)$ SE/RSE episodes described. Failure of lidocaine treatment occurred in 78 of $252(30.9 \%)$ episodes.

In those patients with phenytoin on board during lidocaine administration, there were 20 discrete SE/RSE episodes recorded. Lidocaine administration resulted in seizure reduction in 12 of these $20(60.0 \%)$ episodes, with all resulting in complete seizure control. Eight of these $20(40.0 \%)$ SE/RSE episodes failed lidocaine administration when phenytoin was already on board. 
Table 2: Pediatric articles: lidocaine treatment characteristics, seizure response, and outcome

\begin{tabular}{|c|c|c|c|c|c|c|c|c|}
\hline Reference & $\begin{array}{l}\text { Number of } \\
\text { patients } \\
\text { treated with } \\
\text { lidocaine }\end{array}$ & Lidocaine dose & $\begin{array}{l}\text { Mean duration of } \\
\text { lidocaine } \\
\text { administration (days) }\end{array}$ & $\begin{array}{l}\text { PHT on } \\
\text { board during } \\
\text { lidocaine }\end{array}$ & $\begin{array}{l}\text { Electrographic } \\
\text { seizure response }\end{array}$ & $\begin{array}{l}\text { Recurrence after } \\
\text { withdrawal of } \\
\text { lidocaine }\end{array}$ & $\begin{array}{l}\text { Adverse effects to } \\
\text { lidocaine }\end{array}$ & Patient outcome \\
\hline Aggarwal et al ${ }^{15}$ & 1 & $100 \mathrm{mg}$ IV x 1 & Single bolus & $1 / 1$ & Immediate cessation & $\begin{array}{l}\text { Yes; control for } \\
12 \text { hours }\end{array}$ & None & Unknown \\
\hline Bernhard et al $^{16}$ & 1 & $\begin{array}{l}4 \mathrm{mg} / \mathrm{kg} \text { IV } \times 1 \\
4-6 \mathrm{mg} / \mathrm{kg} / \text { hour infusion started } \\
\text { after recurrence }\end{array}$ & 24 hours & $0 / 1$ & $\begin{array}{l}\text { Transient decrease in } \\
\text { seizures and } \\
\text { cessation of SE }\end{array}$ & Yes & None & $\begin{array}{l}\text { Achieved pre-SE } \\
\text { baseline }\end{array}$ \\
\hline Boylan et a ${ }^{17}$ & $\begin{array}{c}5(6 \text { other } \\
\text { randomized } \\
\text { patients: } 3 \\
\text { treated with } \\
\text { midaz, } 3 \text { with } \\
\text { clonaz) }\end{array}$ & $\begin{array}{l}\text { Phenobarbitone at } 40 \mathrm{mg} / \mathrm{kg} \text { was } \\
\text { ongoing } \\
\text { Lidocaine }=4 \mathrm{mg} / \mathrm{kg} \text { over } 20 \mathrm{~min} \\
\text { then } 2 \mathrm{mg} / \mathrm{kg} / \mathrm{hour} \text { for } 12 \text { hours, if } \\
\text { failure then } 4 \mathrm{mg} / \mathrm{kg} / \mathrm{hour} \\
\text { Midazolam }=60 \mathrm{mcg} / \mathrm{kg} \text { load than } \\
150 \mathrm{mcg} / \mathrm{kg} / \mathrm{hour} \text { for } 12 \text { hours, if } \\
\text { failure then } 300 \mathrm{mcg} / \mathrm{kg} / \mathrm{hr} \\
\text { Clonazepam }=\text { unspecified dose }\end{array}$ & $\begin{array}{l}12 \text { hours of each } \\
\text { therapy, if no } \\
\text { response, then } \\
\text { increase infusions } \\
\text { for another } 12 \text { hours. } \\
\text { If failure of increased } \\
\text { dose, patient } \\
\text { removed from trial. }\end{array}$ & $0 / 5$ & $\begin{array}{l}2 / 5 \text { lidocaine patients } \\
\text { became seizure-free } \\
1 / 5 \text { had } 80 \% \text { reduction } \\
\text { in seizures on EEG } \\
\text { All other infants } \\
\text { (midaz group, or } \\
\text { increased dosing of } \\
\text { lido/midaz, or } \\
\text { clonaz group) had } \\
\text { no response }\end{array}$ & Unknown & None & $\begin{array}{l}\text { Lidocaine group }=3 / 5 \\
\text { severe limitations, } 2 / 5 \\
\text { died } \\
\text { Midazolam }=1 / 3 \text { mild } \\
\text { impairment, } 1 / 3 \\
\text { moderate, } 1 / 3 \text { died } \\
\text { Clonazepam }=1 / 3 \\
\text { moderate impairment, } \\
\text { 1/3 died, 1/3 LTFU }\end{array}$ \\
\hline Dan et al ${ }^{18}$ & 2 & Unknown & Unknown & $1 / 2$ & Failed in both & Unknown & None & $\begin{array}{l}\text { Died (1); required IA and } \\
\text { no impact on outcome } \\
\text { (1) }\end{array}$ \\
\hline Fallah et al ${ }^{19}$ & $\begin{array}{c}10 \text { (rando- } \\
\text { mized } \\
\text { patients: } 10 \\
\text { with midaz; } \\
10 \text { with lido) }\end{array}$ & $\begin{array}{l}\text { All patients: } \\
\text { A. Diazepam }(0.2-0.3 \mathrm{mg} / \mathrm{kg} \text { bolus x2) } \\
\text { B. Phenytoin }(15-20 \mathrm{mg} / \mathrm{kg} \text { load) } \\
\text { C. Phenobarbitone }(10 \mathrm{mg} / \mathrm{kg} \text { over } \\
10 \text { minutes) } \\
\text { If failed above then randomized: } \\
\text { Midaz group }(\mathrm{n}=10): 0.15 \mathrm{mg} / \mathrm{kg} \\
\text { bolus then } 1 \mathrm{mcg} / \mathrm{kg} / \mathrm{hour} \mathrm{infusion} \\
\text { titrated up to } 6 \mathrm{mcg} / \mathrm{kg} \text { until control } \\
\text {-Continued for } 24 \text { hours if } \\
\text { effective, then titrated off } \\
\text { Lidocaine group }(\mathrm{n}=10): 1 \mathrm{mg} / \mathrm{kg} \\
\text { bolus; repeat if no response in } \\
15 \text { minutes, then infusion at } 1 \mathrm{mg} / \\
\mathrm{kg} / \text { hour titrated to } 5 \mathrm{mg} / \mathrm{kg} / \mathrm{hour} \\
\text { until control -Continued for } \\
12 \text { hours at this dose then } \\
\text { titrated off by } 0.5 \mathrm{mg} / \mathrm{kg} / \mathrm{hour} \\
\text { *if either medication failed, } \\
\text { they were stopped and } \\
\text { pentobarb } \\
\text { started }\end{array}$ & 12 hours & $10 / 10$ & $\begin{array}{l}\text { Lidocaine } 5 / 10 \text { seizure } \\
\text { cessation: } \\
-2 / 5 \text { with first bolus } \\
-2 / 5 \text { with second bolus } \\
-1 / 5 \text { with infusion } \\
\text { Midazolam } 2 / 10 \\
\quad \text { seizure cessation }\end{array}$ & Unknown & $\begin{array}{l}\text { Transient } \\
\quad \text { bradycardia (1) }\end{array}$ & Unknown \\
\hline Hamano et $\mathrm{al}^{20}$ & $\begin{array}{l}37(53 \\
\text { episodes of } \\
\text { SE) }\end{array}$ & $\begin{array}{l}\text { Bolus dose: } 0.91-3.33 \mathrm{mg} / \mathrm{kg} \\
\text { Infusion: } 2.59 \mathrm{mg} / \mathrm{kg} / \mathrm{hour} \text { (range: } \\
2-4 \mathrm{mg} / \mathrm{kg} / \mathrm{hour} \text { ) }\end{array}$ & Unknown & $0 / 37$ & $\begin{array}{l}\text { Stopped seizures in } \\
19 / 53 \text { episodes of } \\
\text { SE within } 5 \text { minutes } \\
\text { of Tx }\end{array}$ & Unknown & $\begin{array}{l}\text { Decreased } \mathrm{SpO}_{2} \text { in } \\
1 \text { patient } \\
\text { temporarily }\end{array}$ & Unknown \\
\hline
\end{tabular}




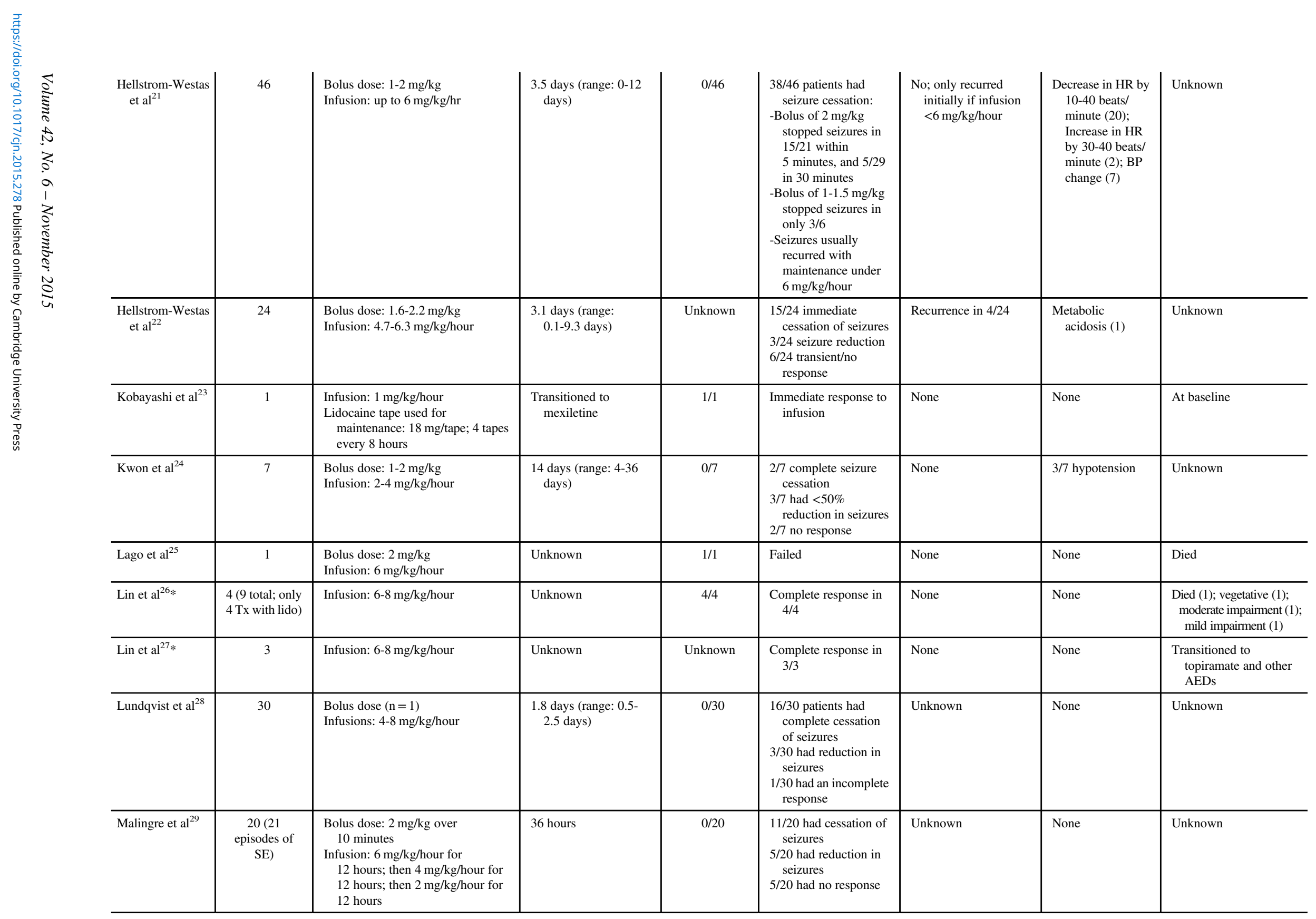




\begin{tabular}{|c|c|c|c|c|c|c|c|c|}
\hline Reference & $\begin{array}{l}\text { Number of } \\
\text { patients } \\
\text { treated with } \\
\text { lidocaine }\end{array}$ & Lidocaine dose & $\begin{array}{l}\text { Mean duration of } \\
\text { lidocaine } \\
\text { administration (days) }\end{array}$ & $\begin{array}{l}\text { PHT on } \\
\text { board during } \\
\text { lidocaine }\end{array}$ & $\begin{array}{l}\text { Electrographic } \\
\text { seizure response }\end{array}$ & $\begin{array}{l}\text { Recurrence after } \\
\text { withdrawal of } \\
\text { lidocaine }\end{array}$ & $\begin{array}{l}\text { Adverse effects to } \\
\text { lidocaine }\end{array}$ & Patient outcome \\
\hline Okumura et al ${ }^{30}$ & $\begin{array}{l}1 \text { ( } 2 \text { cases; } \\
\text { only } 1 \text { Tx with } \\
\text { lido })\end{array}$ & Unknown & Unknown & $1 / 1$ & Failure & Unknown & Unknown & $\begin{array}{l}\text { Moderate impairment, } \\
\text { controlled on multiple } \\
\text { AEDs }\end{array}$ \\
\hline Rey et $\mathrm{al}^{31}$ & 13 & $\begin{array}{l}\text { Infusions: } 4 \mathrm{mg} / \mathrm{kg} / \text { hour for } 1 \text { day; } \\
\text { then } 3 \mathrm{mg} / \mathrm{kg} / \text { hour for } 1 \text { day; then } \\
2 \mathrm{mg} / \mathrm{kg} / \mathrm{hour} \text { for } 1 \text { day, then } \\
1 \mathrm{mg} / \mathrm{kg} / \text { hour for } 1 \text { day }\end{array}$ & 4 days & $0 / 13$ & $\begin{array}{l}\text { 11/13 }(85 \%) \text { seizure } \\
\text { control (effect } \\
\text { within } 13 \text { hours of } \\
\text { starting lido) }\end{array}$ & Unknown & None & Unknown \\
\hline Shany et $\mathrm{al}^{32}$ & $\begin{array}{l}22(30 \text { total; } \\
22 \text { Tx with } \\
\text { lido, } 8 \text { with } \\
\quad \text { midaz) }\end{array}$ & $\begin{array}{l}\text { Bolus dose: } 2 \mathrm{mg} / \mathrm{kg} \text { over } \\
20 \text { minutes } \\
\text { Infusion: } 4 \text { to } 6 \mathrm{mg} / \mathrm{kg} / \mathrm{hour}\end{array}$ & Unknown & $0 / 22$ & $\begin{array}{l}11 / 22 \text { seizure control } \\
6 / 22 \text { partial response } \\
5 / 22 \text { no response }\end{array}$ & Unknown & None & $\begin{array}{r}\text { Died (5); major disability } \\
\text { (7); no complication (9) }\end{array}$ \\
\hline Wakamoto et al $^{33}$ & 1 & Unknown & Unknown & $1 / 1$ & Failure & Unknown & Unknown & Died \\
\hline Wallin et $\mathrm{al}^{34}$ & 3 & Infusion up to $6.8 \mathrm{mg} / \mathrm{kg} /$ hour & $\begin{array}{l}3 \text { days (1); } 3 \text { weeks (1); } \\
3 \text { months (1) }\end{array}$ & $0 / 3$ & $\begin{array}{l}\text { All responded to } \\
\text { therapy }\end{array}$ & $\begin{array}{l}\text { No; recurrence on } \\
\text { initial withdrawal in } \\
\text { case } 2 \text { and 3, but not } \\
\text { after prolonged } \\
\text { infusion }\end{array}$ & None & Unknown \\
\hline Yamamoto et $\mathrm{al}^{35}$ & $\begin{array}{l}16(65 \text { total } \\
\text { studied; } 49 \\
\text { midaz only, } \\
10 \text { lido only, } \\
6 \text { both })\end{array}$ & $\begin{array}{l}\text { Not clear; mean dose } 1.8 \mathrm{mg} / \mathrm{kg} / \\
\text { hour during Tx period }\end{array}$ & Unknown & Not clear & $\begin{array}{l}4 / 16 \text { complete seizure } \\
\text { cessation } \\
9 / 16 \text { reduction in } \\
\text { seizures by }>50 \% \\
3 / 16 \text { reduction in } \\
\text { seizures by }<50 \% \text { or } \\
\text { failure }\end{array}$ & Unclear & $\begin{array}{l}6.3 \% \text { hypotension, } \\
\text { hypersecretion, } \\
\text { abdominal } \\
\text { distension }\end{array}$ & Unclear \\
\hline
\end{tabular}

BP, blood pressure; IV, intravenous; midaz, midazolam; rehab, rehabilitation center; Tx, treatment.

$*$ Lin et $\mathrm{al}^{26}$ and Lin et $\mathrm{al}^{27}$ contain duplicate data, with only the data from Lin et $\mathrm{al}^{26}$ included in the final summary of data. Lin et $\mathrm{al}^{27}$ is the published meeting abstract of Lin et al. ${ }^{26}$ 
Table 3: Pediatric studies: Oxford and GRADE level of evidence

\begin{tabular}{|c|c|c|c|}
\hline Reference & Study type & Oxford $^{38}$ level of evidence & GRADE $^{39-44}$ level of evidence \\
\hline Aggarwal et al & Retrospective case series & 4 & $\mathrm{D}$ \\
\hline Aggarwal et al ${ }^{15}$ & Retrospective case series & 4 & $\mathrm{D}$ \\
\hline Bernhard et $\mathrm{al}^{16}$ & Prospective randomized trial & $2 b$ & $\mathrm{C}$ \\
\hline Boylan et $\mathrm{al}^{17}$ & Retrospective case series & 4 & $\mathrm{D}$ \\
\hline Dan et $\mathrm{al}^{18}$ & Prospective randomized trial & $2 b$ & B \\
\hline${\text { Fallah et } \mathrm{al}^{19}}^{19}$ & Retrospective case series & 4 & $\mathrm{D}$ \\
\hline Hamano et $\mathrm{a}^{20}$ & Retrospective case series & 4 & $\mathrm{D}$ \\
\hline Hellstrom-Westas et $\mathrm{al}^{21}$ & Prospective single arm & $2 b$ & $\mathrm{C}$ \\
\hline Hellstrom-Westas et al $^{22}$ & Retrospective case report & 4 & $\mathrm{D}$ \\
\hline Kobayashi et al ${ }^{23}$ & Retrospective case series & 4 & $\mathrm{D}$ \\
\hline Kwon et al ${ }^{24}$ & Retrospective case report & 4 & $\mathrm{D}$ \\
\hline Lago et $\mathrm{al}^{25}$ & Retrospective case series & 4 & $\mathrm{D}$ \\
\hline Lin et $\mathrm{al}^{26 *}$ & Retrospective case series & 4 & $\mathrm{D}$ \\
\hline Lin et $\mathrm{al}^{27}$ & Retrospective case report & 4 & $\mathrm{D}$ \\
\hline Lundqvist et $\mathrm{al}^{28 *}$ & Prospective single arm & $2 \mathrm{~b}$ & B \\
\hline Malingre et $\mathrm{al}^{29}$ & Retrospective case report & 4 & $\mathrm{D}$ \\
\hline Okumura et al $^{30}$ & Prospective Single arm & $2 \mathrm{~b}$ & $\mathrm{C}$ \\
\hline Rey et $\mathrm{al}^{31}$ & Retrospective case series & 4 & $\mathrm{D}$ \\
\hline Shany et $\mathrm{al}^{32}$ & Retrospective case report & 4 & $\mathrm{D}$ \\
\hline Wakamoto et al $^{33}$ & Retrospective case series & 4 & $\mathrm{D}$ \\
\hline Wallin et al ${ }^{34}$ & Retrospective case series & 4 & $\mathrm{D}$ \\
\hline 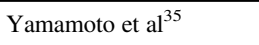 & Retrospective case series & 4 & $\mathrm{D}$ \\
\hline
\end{tabular}

* Lin et $\mathrm{al}^{26}$ and Lin et $\mathrm{al}^{27}$ contain duplicate data, with only the data from Lin et al ${ }^{26}$ included in the final summary of data. Lin et al ${ }^{27}$ is the published meeting abstract of Lin et al. ${ }^{26}$

In comparison, analyzing those patients treated with lidocaine without phenytoin on board recorded a total of 232 discrete SE/RSE episodes. Complete seizure response to lidocaine administration occurred in 131 of the $232(56.5 \%)$ of the SE/RSE episodes. Failure of lidocaine therapy occurred in 70 of the 232 $(30.1 \%)$ of the SE/RSE episodes described.

Focusing on the randomized trials ${ }^{17,19}$ comparing lidocaine treatment to benzodiazepine-based therapy for SE/RSE, one study displayed a $60.0 \%$ seizure response rate to lidocaine (either cessation or $>50 \%$ reduction in seizures), with the benzodiazepine groups failing to demonstrate seizure response. ${ }^{17}$ The second randomized trial displayed a $50 \%$ seizure response rate to lidocaine in the setting of RSE, with only a $20 \%$ response rate in the midazolam group. 19

Recurrence of seizures upon withdrawal of lidocaine occurred in six of the $78(7.7 \%)$ responsive SE/RSE episodes. Recurrence rates were unspecified in 174 of the SE/RSE episodes.

\section{Adverse Effects of Lidocaine}

Only six studies documented adverse events related to lidocaine administration. ${ }^{19-22,25,35}$ Bradycardia and hypotension were noted in 30 and 11 patients, respectively. Other less commonly reported complications were: tachycardia (two), metabolic acidosis (one), and decreased oxygen saturations (one).

\section{Outcome}

Patient outcome was reported sparingly in most studies because the main focus of these reports was the success/failure of lidocaine treatment. In those studies that reported such data, outcomes were as follows: dead (13), major morbidity (14), moderate morbidity (4), and minor/no morbidity (13). These data can be seen in Table 2.

\section{Level of Evidence for Lidocaine}

Based on two independent reviewers, there were a total of 20 original studies reviewed with five representing Oxford level $2 b$ evidence for the administration of lidocaine in pediatric SE/RSE. ${ }^{17,19,22,29,31}$ Fifteen studies represented Oxford level 4 evidence for lidocaine administration in pediatric $\mathrm{SE} /$ RSE. ${ }^{15,16,18,20,1,23-26,27,28,30,32-35}$

Two of the 20 studies met GRADE B level of evidence, ${ }^{19,29}$ three met GRADE C evidence, ${ }^{17,22,31}$ whereas the remaining 15 met GRADE D level of evidence. ${ }^{15,16,18,20,1,23-26,27,28,30,32-35}$ Summary of the level of evidence can be seen in Table 3.

\section{Discussion}

Lidocaine is a type Ib antiarrhythmic agent and sodium channel antagonist commonly used in the cardiac and pain literature. It 
is through its sodium channel blockage that neural conduction is reduced and impeded, leading to its antiarrhythmic and anesthetic properties. Given these effects at the neuronal sodium channel, lidocaine's role as an AED has been investigated. ${ }^{12,14-26}$

Unlike other sodium channel-blocking AEDs, such as phenytoin (also a class Ib antiarrhythmic), its structure includes an aromatic and amine chain motif allowing for binding to the sodium channel via both the channels' pore-lining phenyl-binding site, ${ }^{27,28}$ or via the external amine chain site, both of which lead to the reduction of ion transport across the cellular membrane. Other sodium channel-based AEDs typically only carry a diphenyl motif, solely allowing binding at the pore-lining phenyl sites, ${ }^{13}$ blocking sodium ion transport. Thus, lidocaine can potentially add further sodium channel blockade in the setting of refractory seizures where other sodium channel antagonists are on board because of interaction with the external amine binding site.

To date, small case series have appeared since the 1950s describing the use of lidocaine as an AED, with the majority of the literature focused on the pediatric population. Given the success of lidocaine as an AED in the setting of neonatal and pediatric seizures, ${ }^{10-12}$ we elected to perform a systematic review of the literature to determine its effect on SE and RSE in the adult population.

Through our review, we identified 20 original articles pertaining to the reported usage of lidocaine for control of SE/ RSE in the pediatric population. Nineteen were published manuscripts, whereas one was a published meeting abstract. A total of 235 patients were described in these articles with 252 discrete episodes of SE/RSE treated with lidocaine therapy. Sixteen patients were identified as prospectively enrolled control subjects, receiving benzodiazepine-based therapy in comparison to lidocaine.

The majority of the studies were retrospective case reports/series, with only five being prospective in nature. Looking at the primary outcome of our study (seizure control), $69.0 \%$ of the SE/RSE episodes responded to lidocaine therapy via seizure cessation or greater than $50 \%$ reduction in seizures. Complete seizure cessation was noted in $57.6 \%$, greater than $50 \%$ reduction in $12.3 \%$, and failure of lidocaine therapy was noted in $30.9 \%$. Comparing those patients with and without phenytoin on board during lidocaine administration, seizure cessation occurred in $60.0 \%$ and $56.6 \%$, respectively. In the secondary outcomes, bradycardia and hypotension were commonly reported. Unfortunately, patient outcome data were too sparingly documented for any strong conclusion on the impact of lidocaine therapy in pediatric SE/RSE. A meta-analysis was not possible given the heterogeneous, retrospective nature of the studies available. Based on this review, we can currently provide Oxford level 2b, GRADE C, recommendations for the use of lidocaine for pediatric SE/RSE.

Some important points have arisen from our review. First, the seizure response rate of $69.0 \%$ with lidocaine administration in a population of medically refractory cases is quite high compared with other therapies for RSE. ${ }^{45}$ This may represent a significant publication bias, focused on publishing only positive results with lidocaine for SE/RSE. Second, the seizure cessation rate of $60.0 \%$ to lidocaine whereas phenytoin has already been administered highlights the effectiveness of this medication in the presence of another sodium channel agent, as further emphasized by the $56.5 \%$ cessation rate for those patients not on phenytoin during lidocaine therapy. The effect of the external sodium channel binding motif of lidocaine, not possessed by phenytoin, is the likely reason for the seemingly "additive" benefit of lidocaine in the presence of another sodium channel based AED. Third, the two randomized trials, ${ }^{17,19}$ though small, did demonstrate superior seizure control with lidocaine therapy compared to benzodiazepines when utilized as a second $^{17}$ or fourth ${ }^{19}$ line agent in SE/RSE. Fourth, the seizure recurrence following withdrawal of lidocaine therapy was scarcely described, likely secondary to publication bias or underreporting. Lidocaine treatment is not a long-term solution, but an option during crisis. Seizure response to lidocaine should be met with ongoing adjustment of oral AEDs with the goal of discontinuing intravenous anesthetic agents. Fifth, there did not appear to be a trend to increased efficacy in any particular underlying etiology treated within the studies. Finally, the number of complications described was not insignificant. Hypotension and bradycardia with lidocaine administration likely stems from the class Ib antiarrhythmic effects of lidocaine. It was not clear from the studies included in this review as to whether these side effects occurred during bolus dosing or continuous administration. Similarly, the dose of lidocaine therapy was likely to correlate with these side effects, though not commented on in the studies.

Our review has significant limitations. First, the small number of studies identified, all with small patient populations, makes it difficult to generalize to all pediatric SE/RSE patients. Second, the predominantly retrospective heterogeneous nature of the data makes it difficult to perform a meaningful meta-analysis, resulting in a strictly descriptive analysis. Third, the heterogeneity of prior treatments, time to lidocaine administration, and lidocaine dosage and duration leave the data on seizure responsiveness difficult to interpret. It is even more difficult, on the basis of these data, to recommend a treatment regimen based on lidocaine. Fourth, the outcome data were poorly recorded in the majority of the studies identified. As such, formal comments on the impact of lidocaine therapy on patient outcome during SE/RSE cannot be made at this time. Finally, as previously mentioned, there is likely a significant publication bias in the literature favoring the publication of only positive results with lidocaine therapy for pediatric SE/RSE. Despite these significant limitations, we believe the data provide evidence for the potential benefit of lidocaine therapy in the setting of pediatric SE/RSE.

Future prospective analysis of lidocaine treatment during SE/RSE should be conducted. Formal comparison between phenytoin and lidocaine in a randomized fashion may prove interesting. Furthermore, prospective evaluation of lidocaine as the third-line agent in adult SE/RSE, in comparison to other commonly used agents also should be conducted.

\section{ConClusions}

There currently is Oxford level $2 \mathrm{~b}$, GRADE C, evidence to support the use of lidocaine for SE and RSE in the pediatric population. Further prospective studies of lidocaine administration in this setting are warranted.

\section{DisClosures}

The authors have nothing to disclose.

\section{SUPPLEMENTARY MATERIAL}

To view supplementary material for this article, please visit http://dx.doi.org/10.1017/cjn.2015.278. 


\section{REFERENCES}

1. Bath KG, Scharfman HE. Impact of early life exposure to antiepileptic drugs on neurobehavioral outcomes based on laboratory animal and clinical research. Epilepsy Behav. 2013;26: 427-39.

2. Zhang LL, Zeng LN, Li YP. Side effects of phenobarbital in epilepsy: a systematic review. Epileptic Disord. 2011;13:349-65.

3. Ikonomidou C, Turski L. Antiepileptic drugs and brain development. Epilepsy Res. 2010;88:11-22.

4. Vento M, de Vries LS, Alberola A, Blennow M, Steggerda S, Greisen G, et al. Approach to seizures in the neonatal period: a European perspective. Acta Paediatr. 2010;99:497-501.

5. Sánchez Fernández I, Abend NS, Agadi S, An S, Arya R, Carpenter $\mathrm{JL}$, et al. Gaps and opportunities in refractory status epilepticus research in children: a multi-center approach by the Pediatric Status Epilepticus Research Group (pSERG). Seizure. 2014; 23:87-97.

6. Capovilla G, Beccaria F, Beghi E, Minicucci F, Sartori S, Vecchi M. Treatment of convulsive status epilepticus in childhood: recommendations of the Italian League Against Epilepsy. Epilepsia. 2013;54(Suppl 7):23-34.

7. Brophy GM, Bell R, Claassen J, Alldredge B, Bleck TP, Glauser T, et al. Guidelines for the evaluation and management of status epilepticus. Neurocrit Care. 2012;17:3-23.

8. Ottosson JO. Effect of lidocaine and procaine on the electroshock seizure threshold, with a comparison of the effects of phenytoin and phenobarbital. Acta Psychiatr Scand Suppl. 1960;35(145): 33-48.

9. Borowicz KK, Banach M. Antiarrhythmic drugs and epilepsy. Pharmacol Rep. 2014 Aug;66(4):545- 51.

10. Cervenka MC, Hartman AL, Venkatesan A, Geocadin RG, Kossoff $\mathrm{EH}$. The ketogenic diet for medically and surgically refractory status epilepticus in the neurocritical care unit. Neurocrit Care. 2011;15:519-24

11. De Giorgio CM, Altman K, Hamilton-Byrd E, Rabinowicz AL. Lidocaine in refractory status epilepticus: confirmation of efficacy with continuous EEG monitory. Epilepsia. 1992;33:913-6.

12. Yang YC, Huang CS, Kuo CC. Lidocaine, Carbamazepine, and Imipramine have partially overlapping binding sites and additive inhibitory effect on neuronal $\mathrm{Na}$ channels. Anesthesiology. 2010;113:160-74.

13. Kuo C-C. A common anticonvulsant binding site for phenytoin, carbamazepine, and lamotrigine in neuronal $\mathrm{Na}$ channels. Mol Pharmacol. 1998;54:712-21.

14. Kuo C-C, Lou B-S, Huang R-C. Inhibition of $\mathrm{Na}(+)$ current by diphenhydramine and other diphenyl compounds: molecular determinants of selective binding to the inactivated channels. Mol Pharmacol. 2000;57:135-43.

15. Aggarwal P, Wali JP. Lidocaine in refractory status epilepticus: a forgotten drug in the emergency department. Am J Emerg Med. 1993;11:243-4.

16. Bernhard CG, Bohm E, Hojeberg S. A new treatment for status epilepticus. AMA Arch Neurol Psychiatry. 1955;74:208-14.

17. Boylan GB, Rennie JM, Chorley G, Pressler RM, Fox GF, et al. Second-line anticonvulsant treatment of neonatal seizures: a video-EEG monitoring study. Neurology. 2004;62:486-8.

18. Dan B, Boyd SG. Stimulus-sensitive burst-spiking in burstsuppression in children: implications for management of refractory status epilepticus. Epileptic Disord. 2006;8:143-50.

19. Fallah R, Gofrani M. Comparison of intravenous lidocaine and midazolam infusion for refractory status epilepticus in children. J Ped Neurol. 2007;5:287-90.

20. Hamano S, Sugiyama N, Yamashita S, Tanaka M, Hayakawa M, Minamitani M, et al. Intravenous lidocaine for status epilepticus during childhood. Dev Med Child Neurol. 2006;48:220-2.

21. Hellström-Westas L, Westgren U, Rosén I, Svenningsen NW. Lidocaine for treatment of severe seizures in newborn infants. I. Clinical effects and cerebral electrical activity monitoring. Acta Paediatr Scand. 1988;77:79-84.

22. Hellström-Westas L, Svenningsen NW, Westgren U, Rosén I, Lagerström PO. Lidocaine for treatment of severe seizures in newborn infants. II. Blood concentrations of lidocaine and metabolites during intravenous infusion. Acta Paediatr. 1992; 81:35-9.

23. Kobayashi K, Ito M, Miyajima T, Fujii T, Okuno T. Successful management of intractable epilepsy with intravenous lidocain and lidocain tapes. Pediatr Neurol. 1999;21:476-80.

24. Kwon SH, Seo HE, Hwang SK. The effectiveness and tolerability of adjunctive treatment with lidocaine in children with refractory status epilepticus. J Neurol. 2013;260(Suppl 1):S1-280.

25. Lago P, Boniver C, Casara GL, Laverda AM, Fiore A, Salvadori S, et al. Neonatal tuberous sclerosis presenting with intractable seizures. Brain Dev. 1994;16:257-9.

26. Lin JJ, Lin KL, Wang HS, Hsia SH, Wu CT. Effect of topiramate, in combination with lidocaine, and phenobarbital, in acute encephalitis with refractory repetitive partial seizures. Brain Dev. 2009;31:605-11.

27. Lin J, Lin K, Wang H. High dose lidocaine in the treatment of acute encephalitis with repetitive partial seizures in children. Epilepsia. 2007;48:154.

28. Lundqvist M, Agren J, Hellström-Westas L, Flink R, Wickström R. Efficacy and safety of lidocaine for treatment of neonatal seizures. Acta Paediatr. 2013;102:863-7.

29. Malingré MM, Van Rooij LG, Rademaker CM, Toet MC, Ververs TF, van Kesteren C, et al. Development of an optimal lidocaine infusion strategy for neonatal seizures. Eur J Pediatr. 2006;165: 598-604.

30. Okumura A, Komatsu M, Abe S, Kitamura T, Matsui K, Ikeno M, et al. Amplitude-integrated electroencephalography in patients with acute encephalopathy with refractory, repetitive partial seizures. Brain Dev. 2011;33:77-82.

31. Rey E, Radvayani-Bouvet MF, Bodiou C, Richard MO, Torricelli A, Walti $\mathrm{H}$, et al. Intravenous lidocaine in the treatment of convulsions in the neonatal period: monitoring plasma levels. Ther Drug Monit. 1990;12:316-20.

32. Shany E, Benzaqen O, Watemberg N. Comparison of continuous drip of midazolam or lidocaine in the treatment of intractable neonatal seizures. J Child Neurol. 2007;22:255-9.

33. Wakamoto H, Takahashi Y, Ebihara T, Okamoto K, Hayashi M, Ichiyama T, et al. An immunologic case study of acute encephalitis with refractory, repetitive partial seizures. Brain Dev. 2012;34:763-7.

34. Wallin A, Nergårdh A, Hynning PA. Lidocaine treatment of neonatal convulsions, a therapeutic dilemma. Eur J Clin Pharmacol. 1989;36:583-6

35. Yamamoto H, Aihara M, Niijima S, Yamanouchi H. Treatments with midazolam and lidocaine for status epilepticus in neonates. Brain Dev. 2007;29:559-64.

36. Higgins JPT, Green S. eds. Cochrane handbook for systematic reviews of interventions, version 5.1.0. Available at: http:handbook.cochrane.org.

37. Moher D, Liberati A, Tetzlaff J, Altman DG, Group P. Preferred reporting items for systematic reviews and meta-analysis: the PRISMA statement. Ann Intern Med. 2009;151:264-9.

38. Phillips B, Ball C, Sackett D, Straus S, Haynes B, Dawes M. Oxford Centre for Evidence-Based Medicine Levels of Evidence. Version 2009. Available at: http://www.cebm.net/?o=1025.

39. Guyatt GH, Oxman AD, Vist G, Kunz R, Falck-Ytter Y, Alonso-Coello P, et al. Rating quality of evidence and strength of recommendations GRADE: an emerging consensus on rating quality of evidence and strength of recommendations. BMJ. 2008;336:924-6.

40. Guyatt GH, Oxman AD, Kunz R, Vist GE, Falck-Ytter Y, Schünemann HJ, et al. Rating quality of evidence and strength of recommendations: What is "quality of evidence" and why is it important to clinicians? BMJ. 2008;336:995-8.

41. Schünemann HJ, Oxman AD, Brozek J, Glasziou P, Jaeschke R, Vist GE, et al. Grading quality of evidence and strength of recommendations for diagnostic tests and strategies. BMJ. 2008;336: 1106-10.

42. Guyatt GH, Oxman AD, Kunz R, Jaeschke R, Helfand M, Liberati A, et al. Rating quality of evidence and strength of recommendations: incorporating considerations of resources use into grading recommendations. BMJ. 2008:336:1170-3. 
43. Guyatt GH, Oxman AD, Kunz R, Falck-Ytter Y, Vist GE, Liberati A, et al. Rating quality of evidence and strength of recommendations: going from evidence to recommendations. BMJ. 2008;336:1049-51. 44. Jaeschke R, Guyatt GH, Dellinger P, Schünemann H, Levy MM, Kunz R, et al. Use of GRADE grid to reach decisions on clinical practice guidelines when consensus is elusive. BMJ. 2008; 337:a744.

45. Shorvon S, Ferlisi M. The outcome of therapies in refractory and super-refractory status convulsive epilepticus and recommendations for therapy. Brain. 2012;135:2314-28. 